\title{
Models and methods for subject specialization deepening of regional constructional enterprises by the mobile units' relocation
}

\author{
Sergey Shulzhenko ${ }^{1,{ }^{*}}$, Alexandr Zelentsov ${ }^{1}$, Artur Grebennikov ${ }^{1}$, and Mikhail Danilochkin ${ }^{1}$ \\ ${ }^{1}$ Moscow State University of Civil Engineering, 26, Yaroslavskoe shosse, 129337, Moscow, Russia
}

\begin{abstract}
This article shows the amount of construction and installation works at the regional level that are formed according to the individual cluster territories, considering the specialization of the production development. For their implementation, it is necessary either to change the specialization of contracting capacities, or to use them with the consideration of the movement mobility in development zones.
\end{abstract}

\section{Introduction}

In the planned management system, execution orders for certain types of constructionassembly works and formation of annual unloading capacity contractors ' programs were carried out on a territorial and sectoral principle. There was not much of a competition. The municipal administration prescribed in advance the consolidation of "Local" construction capacity, thereby forming their load. In 2002 the contracts' tendering was implemented, that influenced a lot in initial loading conditions of the constriction capacity both in territorial dispersion and specialization ways. As example of Tula region, this situation can be considered as the most typical for Central Federal District, thus the issue of the loading construction capacity can be formulated in a way:

- there are social development territory plans, that are the base of formulation the amount of construction and assembly works at the objects, including technological and industry specialization; [1]

-the tender documentation is being prepared by the administration of the municipal structures according to the alleged general contract;

-it is required to predict the strategic utilization of construction capacities, including their specializations, mobility and the possibility of involvement of executors from the adjoining territories. [2-3]

\section{Materials and methods}

Additional expenditure $\left(\mathrm{C}_{\mathrm{st}}{ }^{\mathrm{T}}\right)$, emerging as a result of variability of the progressive growth of construction-assembly works from optimum alternative due to the intensive probabilistic factors, are accepted for following calculation:

\footnotetext{
* Corresponding author: a.yurgaitis@niiexp.com
} 


$$
C_{s t}^{T}=d \cdot\left(V_{s t}-\gamma_{s t} \cdot V_{s t-1}\right)=d_{s} \cdot\left|\Delta_{s t}\right|,
$$

where $C_{s t}^{T}$ - organizational expenses in the reporting period;

$V_{s t}, \gamma_{s t}$ - specific gravity of construction and assembly works due to the rate intensity in the reporting period;

$\Delta_{s t}-$ variance between the level of construction-assembly works of the specified organizational structure and optimal level of the reporting period, considering probabilistic factors. Indicators of interrelationship are taken to equate to 0,14 or 0,05 for stationary organizations, considering the positive and negative dynamics of variability; 0,14 is taken in the process of establishing mobile organizations and 0,09 or 0,04 - during the years of its operation with various indices range changing of construction and installation works. [4-6]

\begin{tabular}{|l|l|}
\hline \multicolumn{2}{|c|}{ Initial data } \\
\hline $\begin{array}{l}\text { about construction organization } \\
\text { the list of organizations, } \mathrm{s}\end{array}$ & about the area \\
$\begin{array}{l}\text { the scope of work by type and } \\
\text { area in the base year, } \mathrm{V}_{\mathrm{st}} \\
\text { per year, } \mathrm{t} \\
\text { the service area (the list of the } \\
\text { allowable construction areas), } \mathrm{n}\end{array}$ & $\begin{array}{l}\text { average distance between areas, } \mathrm{r}_{\min } \\
\end{array}$ \\
\hline
\end{tabular}

Formation of a distribution option of scope of work for each type of works in each area by construction organization

\section{II}

Determination of the main characteristics of distribution for scope of work:

1) the scope of work of the organization: $V_{s t}=\sum_{i, n} V_{n s t}^{i}$

2) reduced scope of work: $w_{s t}=\sum_{i, n} v_{n s t}^{i c p} q_{i}$

3) the growth rate of scope of work and the reduced scope of work $y_{\mathrm{st}}$

4) the service area of the organization - the list of areas n, where $\sum V_{n s t}^{i} \geq 0$

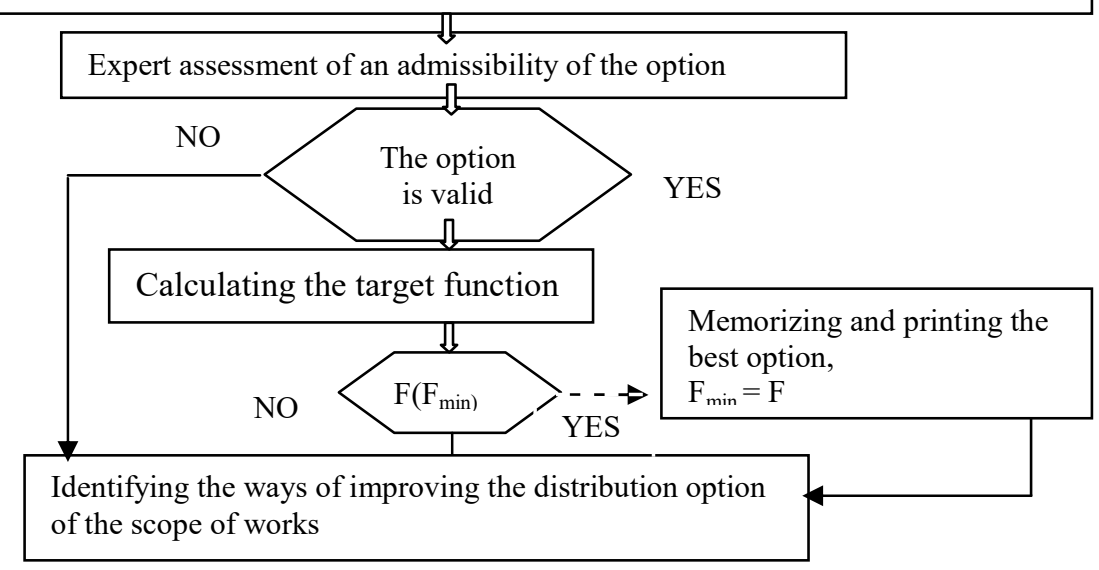

Fig. 1. Algorithm of level diversification for construction-assembly works between organizational structures. 
Using the coefficients of labor intensity specializations and dispersion of construction types, that are shown in table 2, the resulting level of construction-assembly works for the organizational structure is:

$$
\mathrm{W}=50039 \text { thousands of roubles }
$$

The entropy of a specialized level reflection for the construction-assembly works for the organizational structure is:

$$
\mathrm{H}=0,23
$$

As a result:

$$
\mathrm{C}_{\mathrm{st}}{ }^{\mathrm{cr}}=0,02 \cdot 50039 \cdot 0,23=230 \text { thousands of roubles }
$$

Table 1 identifies the dispersal costs on the location of construction objects. It is calculated upon the formula:

$$
C_{s t}^{c r}=\frac{d}{100} * V * \frac{R_{c p}}{100}
$$

where $V$ - level of a construction spread, thousands of roubles;

$\mathrm{R}_{\mathrm{cp}}-$ servicing diapason of construction structure, $\mathrm{km}$;

$d$-dispersed costs, $\%$ of the scope of construction-assembly works.

The quantity of $d$ shall be assumed to be 2,$1 ; 2,3 ; 2,5$, according to the third, second and first groups of stationary organizations according to specifications and codes of practice or shall be equal to 1,79 for mobile organizations. [7-11]

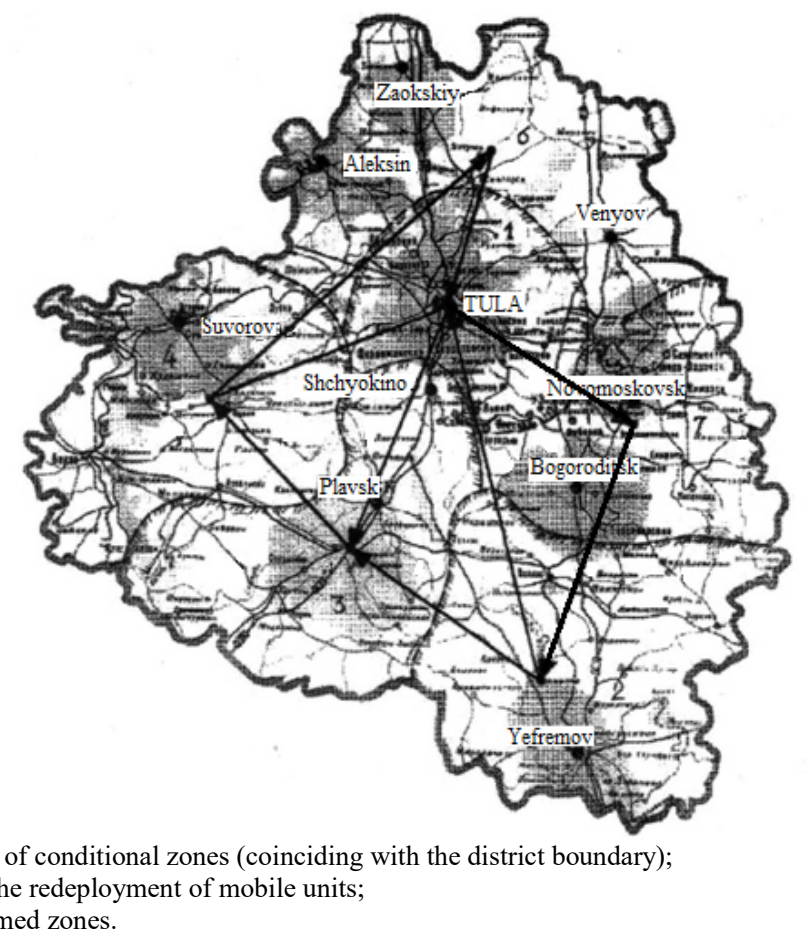

Fig. 2. The scheme of redistribution of territorial divisions on the example of the regional level. 
Table 1. The costs, that associated with the dispersal of construction.

\begin{tabular}{|c|c|c|c|c|c|c|c|c|c|}
\hline \multirow[t]{2}{*}{ Indicator } & \multirow[t]{2}{*}{ Year } & \multicolumn{6}{|c|}{ The area of the region } & \multirow[t]{2}{*}{ MSO } & \multirow[t]{2}{*}{ Total } \\
\hline & & 1 & 2 & 3 & 4 & 5 & 6 & & \\
\hline $\begin{array}{l}\text { Basic version } \\
\text { Scope } \\
\text { constructi of on } \\
\text { and assembly } \\
\text { works, } \\
\text { thousands of } \\
\text { roubles }\end{array}$ & $\begin{array}{l}1999 \\
2000 \\
2001\end{array}$ & $\begin{array}{l}268139 \\
372445 \\
578780\end{array}$ & $\begin{array}{l}170555 \\
236902 \\
368145\end{array}$ & $\begin{array}{l}143906 \\
199886 \\
310622\end{array}$ & $\begin{array}{l}154620 \\
214768 \\
333749\end{array}$ & $\begin{array}{l}172500 \\
239602 \\
372342\end{array}$ & $\begin{array}{l}149429 \\
207556 \\
322542\end{array}$ & $\begin{array}{l}0 \\
0 \\
0\end{array}$ & $\begin{array}{l}1059149 \\
1471159 \\
2286180\end{array}$ \\
\hline $\begin{array}{l}\text { The average } \\
\text { distance of } \\
\text { relocation, } \mathrm{km}\end{array}$ & & 32 & 45,8 & 54 & 48,7 & 54,9 & 47,8 & - & - \\
\hline OTUSP groups & & 3 & 2 & 1 & 2 & 2 & 1 & - & - \\
\hline $\begin{array}{l}\text { The costs } \\
\text { associated with } \\
\text { the dispersal of } \\
\text { construction, \% } \\
\text { to scope of } \\
\text { construction } \\
\text { and assembly } \\
\text { works per } 100 \\
\mathrm{~km} \\
\text { Average } \\
\text { distance } \\
\text { Relocation }\end{array}$ & & 2,1 & 2,3 & 2,5 & 2,3 & 2,3 & 2,5 & - & - \\
\hline $\begin{array}{l}\text { Likewise, } \\
\text { thousands of } \\
\text { roubles }\end{array}$ & $\begin{array}{l}1999 \\
2000 \\
2001\end{array}$ & $\begin{array}{l}1802 \\
2503 \\
3889\end{array}$ & $\begin{array}{l}1797 \\
2496 \\
3878\end{array}$ & $\begin{array}{l}1943 \\
2698 \\
4193\end{array}$ & $\begin{array}{l}1732 \\
2406 \\
3738\end{array}$ & $\begin{array}{l}2178 \\
3025 \\
4702\end{array}$ & $\begin{array}{l}1786 \\
2480 \\
3854\end{array}$ & $\begin{array}{l}- \\
- \\
-\end{array}$ & $\begin{array}{l}11237 \\
15608 \\
24255\end{array}$ \\
\hline $\begin{array}{l}\text { Proposed } \\
\text { option Scope of } \\
\text { construction } \\
\text { and assembly } \\
\text { works, } \\
\text { thousands of } \\
\text { roubles }\end{array}$ & $\begin{array}{l}1999 \\
2000 \\
2001\end{array}$ & $\begin{array}{l}264172 \\
366935 \\
570217\end{array}$ & $\begin{array}{l}154684 \\
214862 \\
333894\end{array}$ & $\begin{array}{l}132005 \\
183356 \\
284933\end{array}$ & $\begin{array}{l}134786 \\
187219 \\
290937\end{array}$ & $\begin{array}{l}168533 \\
234092 \\
363779\end{array}$ & $\begin{array}{l}121661 \\
168986 \\
262604\end{array}$ & $\begin{array}{l}74305 \\
101709 \\
163816\end{array}$ & $\begin{array}{l}1050146 \\
1457159 \\
2270180\end{array}$ \\
\hline $\begin{array}{l}\text { The average } \\
\text { distance of } \\
\text { relocation, } \mathrm{km}\end{array}$ & $\begin{array}{l}1999 \\
2000 \\
2001\end{array}$ & $\begin{array}{l}32 \\
32 \\
32\end{array}$ & $\begin{array}{l}45,8 \\
45,8 \\
45,8\end{array}$ & $\begin{array}{l}54 \\
54 \\
54\end{array}$ & $\begin{array}{l}48,7 \\
48,7 \\
48,7\end{array}$ & $\begin{array}{l}54,9 \\
54,9 \\
54,9\end{array}$ & $\begin{array}{l}47,8 \\
47,8 \\
47,8\end{array}$ & $\begin{array}{l}71,3 \\
71,3 \\
71,3\end{array}$ & $\begin{array}{l}- \\
- \\
-\end{array}$ \\
\hline OTUSP groups & & 3 & 2 & 1 & 2 & 2 & 1 & 3 & - \\
\hline $\begin{array}{l}\text { The costs } \\
\text { associated with } \\
\text { the dispersal of } \\
\text { construction, \% } \\
\text { to scope of } \\
\text { construction } \\
\text { and assembly } \\
\text { works per } 100 \\
\text { km } \\
\text { Average } \\
\text { distance } \\
\text { Relocation }\end{array}$ & & 2,1 & 2,3 & 2,5 & 2,3 & 2,3 & 2,5 & 1,79 & - \\
\hline $\begin{array}{l}\text { Likewise, } \\
\text { thousands of } \\
\text { roubles }\end{array}$ & $\begin{array}{l}1999 \\
2000 \\
2001\end{array}$ & $\begin{array}{l}1775 \\
2466 \\
3832\end{array}$ & $\begin{array}{l}1629 \\
2263 \\
3517\end{array}$ & $\begin{array}{l}1782 \\
2475 \\
3847\end{array}$ & $\begin{array}{l}1510 \\
2097 \\
3259\end{array}$ & $\begin{array}{l}2128 \\
2956 \\
4593\end{array}$ & $\begin{array}{l}1454 \\
2019 \\
4593\end{array}$ & $\begin{array}{c}949 \\
1298 \\
2091\end{array}$ & $\begin{array}{l}11227 \\
15575 \\
24277\end{array}$ \\
\hline
\end{tabular}

\section{Results and discussion}

A basic and expected comparison estimated in table 2, that was carry out different ways, considering the redistributions of the regional level construction program in mutual relations of organizations, specifically stationary and mobile organizational structures. The 
three-year program is economically effective by the amount of 6585 thousand roubles, based on the development of functionality of mobile organizational structures. [12-15]

Table 2. The comparison of options between basic and prospective levels in view of the amount of consolidated costs.

\begin{tabular}{|c|c|c|c|c|c|c|}
\hline \multirow[b]{2}{*}{ № } & \multirow[b]{2}{*}{ Indicator } & \multicolumn{3}{|c|}{ Years } & \multirow[b]{2}{*}{ Total } & \multirow{2}{*}{$\begin{array}{c}\text { Total } \\
\text { based on } \\
\text { the time } \\
\text { factor }\end{array}$} \\
\hline & & 1999 & 2000 & 2001 & & \\
\hline 1 & Reduction coefficient & 0.926 & 0.857 & 0.794 & - & - \\
\hline 2 & $\begin{array}{c}\text { Estimated cost of } \\
\text { construction and } \\
\text { assembly by the region, } \\
\text { thousands of roubles }\end{array}$ & 1059149 & 1471159 & 2286180 & 4816488 & 4056819 \\
\hline 3 & $\begin{array}{l}\text { The same, carried out by } \\
\text { mobile construction } \\
\text { organization }\end{array}$ & 74605 & 101709 & 163816 & 339830 & 286042 \\
\hline 4 & $\begin{array}{l}\text { Additional expenditure, } \\
\text { associated with growth } \\
\text { rate deviation of scope of } \\
\text { construction-assembly } \\
\text { works from «normal» } \\
\text { level, thousands of } \\
\text { roubles }\end{array}$ & $\begin{array}{l}28403 \\
27142\end{array}$ & $\begin{array}{l}55223 \\
53173\end{array}$ & $\begin{array}{l}110482 \\
107135\end{array}$ & $\begin{array}{l}194107 \\
187451\end{array}$ & $\begin{array}{l}161347 \\
155767\end{array}$ \\
\hline 5 & $\begin{array}{l}\text { Costs, associated with the } \\
\text { organization's } \\
\text { specialization, thousands } \\
\text { of roubles }\end{array}$ & $\begin{array}{l}39599 \\
37475\end{array}$ & $\begin{array}{l}55003 \\
52053\end{array}$ & $\begin{array}{l}85474 \\
80889\end{array}$ & $\begin{array}{l}180075 \\
170417\end{array}$ & $\begin{array}{l}151673 \\
143538\end{array}$ \\
\hline 6 & $\begin{array}{l}\text { Costs, associated with the } \\
\text { dispersion of } \\
\text { construction, thousands } \\
\text { of roubles }\end{array}$ & $\begin{array}{l}11237 \\
11227\end{array}$ & $\begin{array}{l}15608 \\
15575\end{array}$ & $\begin{array}{l}24255 \\
24277\end{array}$ & $\begin{array}{l}51100 \\
51079\end{array}$ & $\begin{array}{l}43041 \\
43020\end{array}$ \\
\hline 7 & $\begin{array}{c}\text { Additional costs } \\
\text { associated with the } \\
\text { mobile nature of the } \\
\text { construction-assembly } \\
\text { works, thousands of } \\
\text { roubles }\end{array}$ & 2601 & 3560 & 5734 & 11894 & 10011 \\
\hline 8 & $\begin{array}{l}\text { Total expenses accounted } \\
\text { for (sum of lines 4-7) }\end{array}$ & $\begin{array}{l}79238 \\
77702\end{array}$ & $\begin{array}{l}125833 \\
123344\end{array}$ & $\begin{array}{l}220211 \\
216397\end{array}$ & $\begin{array}{l}425282 \\
417442\end{array}$ & $\begin{array}{l}356061 \\
349476\end{array}$ \\
\hline 9 & Choosing the best option & & & & & \\
\hline 10 & Economic effect & 1537 & 2490 & 3814 & 7840 & 6585 \\
\hline 11 & $\begin{array}{l}\text { The same, } \% \text { of the } \\
\text { estimated cost of the } \\
\text { construction-assembly } \\
\text { work across the region } \\
\text { (line } 10 / \text { line } 2 * 100 \% \text { ) }\end{array}$ & & & & & \\
\hline 12 & $\begin{array}{l}\text { The same, } \% \text { of the } \\
\text { estimated cost of the } \\
\text { construction-assembly } \\
\text { work of the organization } \\
\text { (line } 10 / \text { line } 3 * 100 \% \text { ) }\end{array}$ & 2.07 & 2.45 & 2.33 & 2.31 & 2.30 \\
\hline
\end{tabular}

Considering the whole estimate shows, that calculated economic efficiency level of the annual effect is about $0,16 \%$ of an estimate at the regional level. The mobile organizational structure directly shows, that the level ranges about $2,3 \%$ of total scope of construction- 
assembly works for accounting period due to reallocations of specialization and improving the uniformity throughout the entire period of operation.

In conclusion, it would appear that:

- trends and progress in organizational and technological functioning of organizational structures at the specialize level are objectively existing. This is the result of enhancing technology specialization;

- progressive harnessing modern technologies and types of building materials

is one of the main development directions of specialized construction organizations; the specialized level of executors continues to improve and the economic efficiency of capital investments in regional construction is increasing.

\section{References}

1. Chao Lu, Feifan Chang, Ke Rong, Yongjiang Shi, Xiaoyu Yu, International Journal of Production Economics 107583 (2019)

2. E.G. Gasho, E.V. Repetskaya, V.N. Bandurist, Energy saving 8, 1-14 (2010)

3. N.A. Anisova, Development of cluster theory: a typical model and examples of application. Monograph (Biblio-Globus, Moscow, 2014)

4. S.P. Filippov, Gas business 2, $60-64$ (2005)

5. M.R. Pinskaya, L.A. Ziganina, Innovative development of the economy 6, 90 (2015)

6. L.A. Aguzarova, Taxes and taxation, 279 - 285 (2015)

7. M. Rogalska, W. Bozejko, Z. Hejducki, M. Wodecki, ISARC 2008 - Proceedings from the 25th International Symposium on Automation and Robotics in Construction (2008)

8. Z. Hejducki, Engineering, Construction and Architectural Management 11, 20-32 (2004)

9. E.I. Dobrolyubova, Regional Economics. South of Russia 1, 95 - 105 (2017)

10. D.A Endovitsky, N.P. Lyubushin, N.E. Babicheva, O.M. Kupryushina, Economic analysis: theory and practice 12, $42-65$ (2016)

11. Increasing investment activity in the Russian economy and the development of the construction complex (AINES, Moscow, 1997)

12. M.V. Gryazev, A.L. Sabinina, N.A. Shulzhenko, Finance and credit 2(8), 174-198 (2018)

13. Bingjing Li, Journal of International Economics 114, 346-361 (2018)

14. Yeonha Jung, Journal of Development Economics 143, 102432 (2020)

15. Dong Soon Choi, Richard Ready, Resource and Energy Economics, 101108 (2019) 